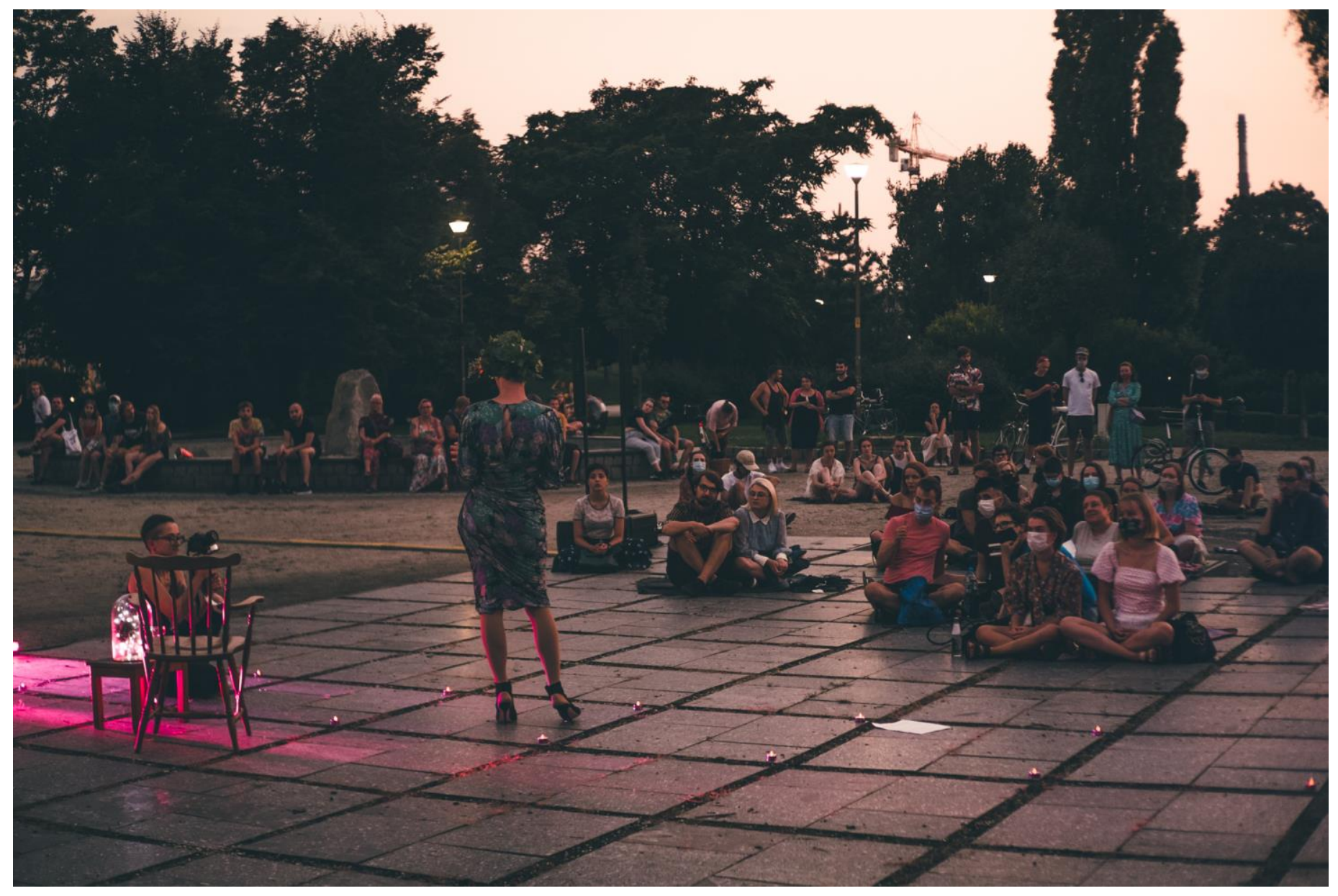

Liliana Piskorska, Sosna z sześcioma rękami, dokumentacja performance, Wzgórze Słowiańskie we Wrocławiu, 2020, fot. Wojciech Chrubasik 


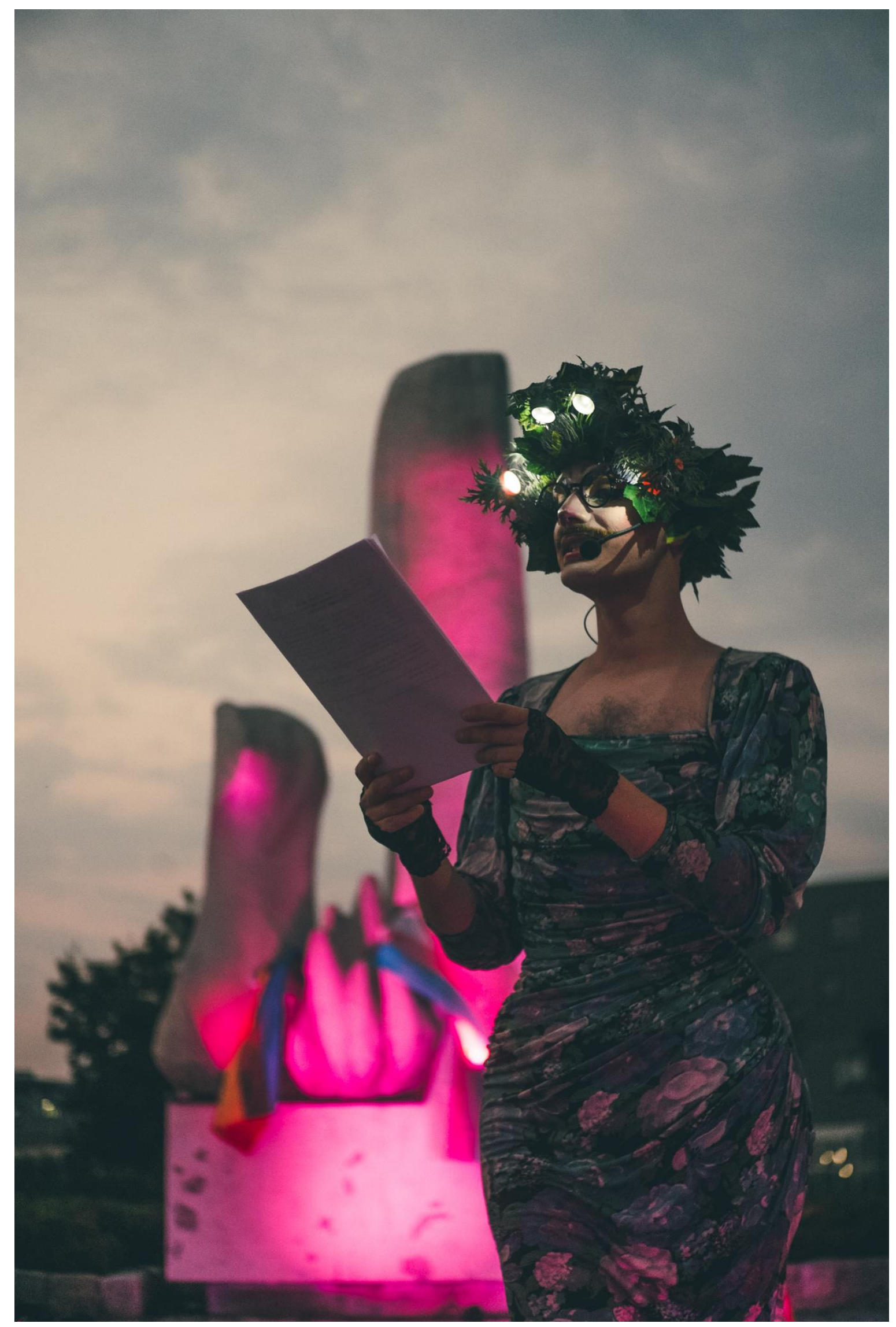

Liliana Piskorska, Sosna z sześcioma rękami, dokumentacja performance, Wzgórze Słowiańskie we Wrocławiu, 2020, fot. Wojciech Chrubasik 


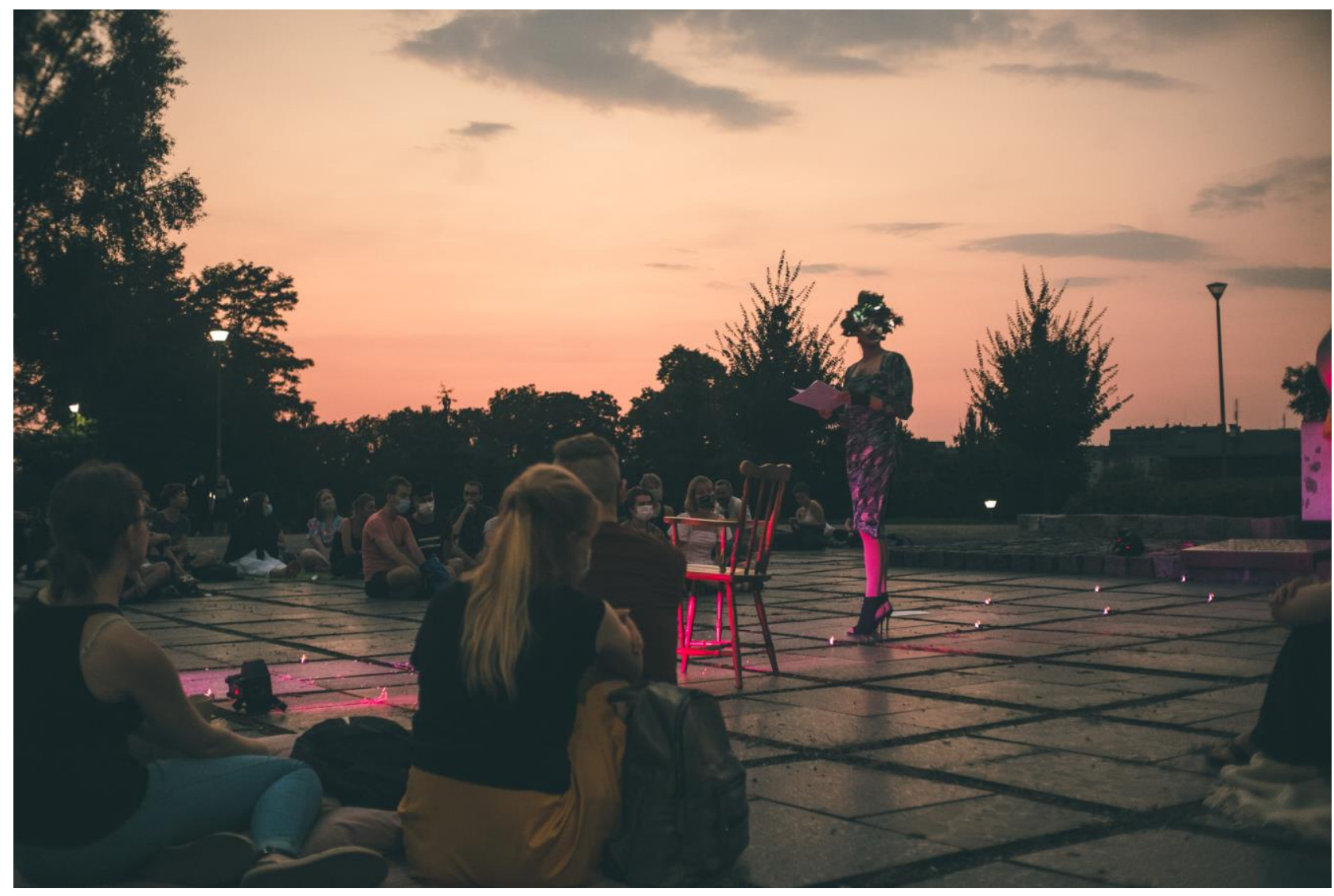

Liliana Piskorska, Sosna z sześcioma rękami, dokumentacja performance, Wzgórze Słowiańskie we Wrocławiu, 2020, fot. Wojciech Chrubasik 


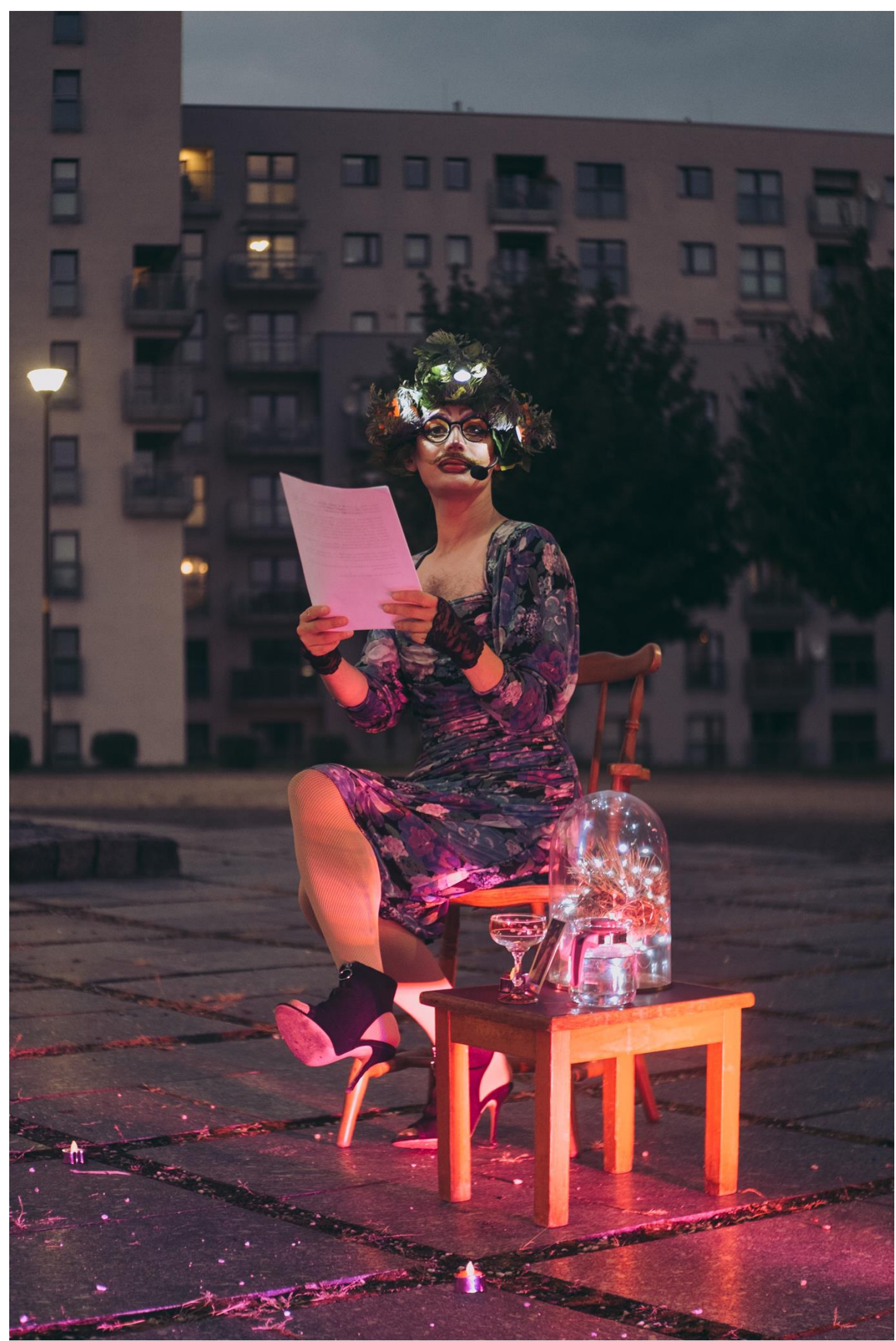

Liliana Piskorska, Sosna z sześcioma rękami, dokumentacja performance, Wzgórze Słowiańskie we Wrocławiu, 2020, fot. Wojciech Chrubasik 


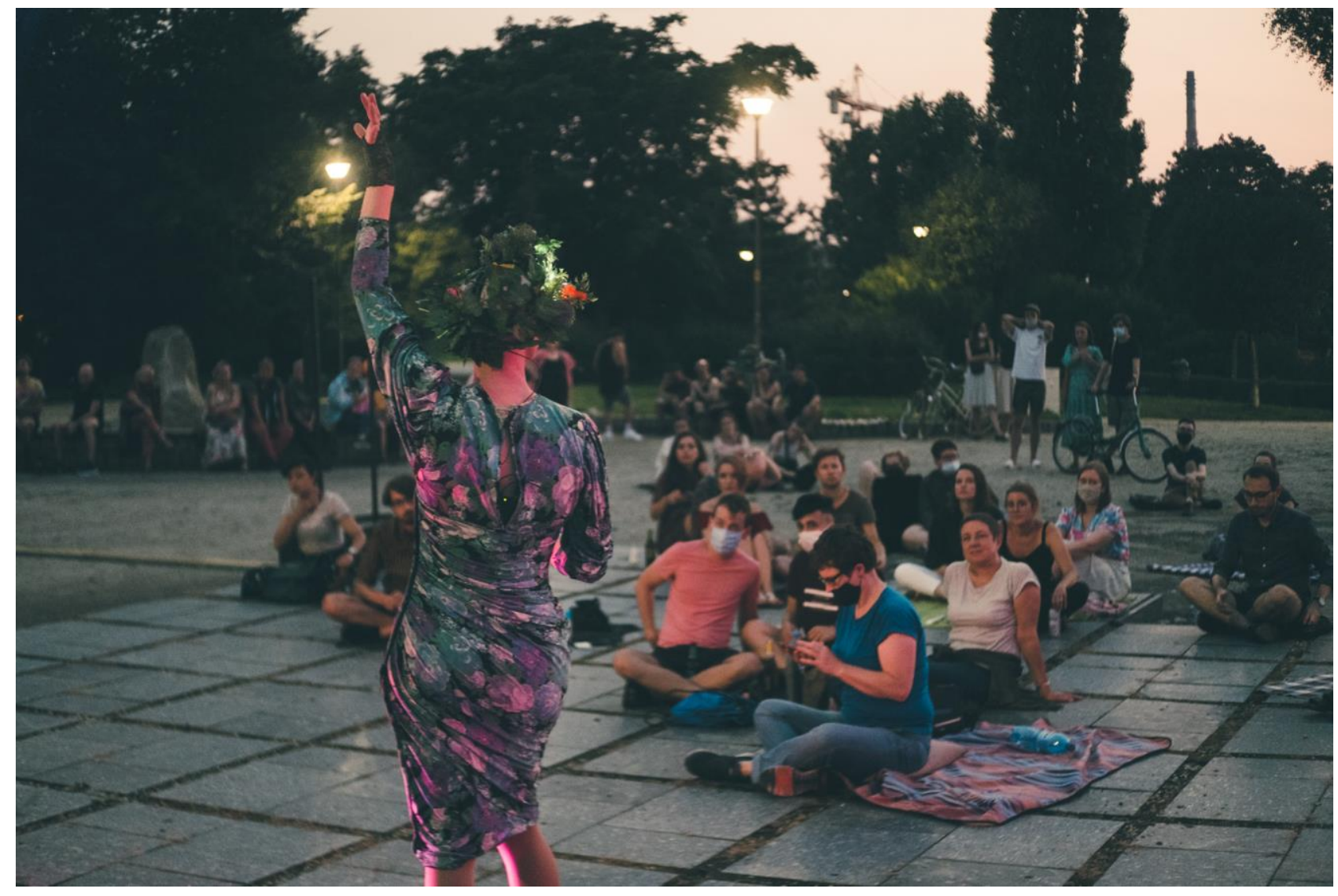

Liliana Piskorska, Sosna z sześcioma rękami, dokumentacja performance, Wzgórze Słowiańskie we Wrocławiu, 2020, fot. Wojciech Chrubasik 


\section{Sosna z sześcioma rękami}

https://doi.org/10.51897/interalia/NGCR5135

\section{Liliana Piskorska}

Na szerokim pasie nizin przetkanych błękitną nicią rzek, stało miasto całe złote. A w tym mieście było wzgórze całe z gruzów usypane, a na wzgórzu rosła sosna, a na sośnie sześć było rąk.

A to wzgórze niezmierne, że wierzchu za chmurami nie widać, dźwiga się stromo ku niebu, a na nim ze wszystkich stron las czarny. Ogromne dęby, sosny, buki, jodły - jedne na drugich wyrastają. Sterczy drzewo ponad drzewem, coraz wyżej, coraz wyżej. Pomiędzy nimi, na ziemi, gąszcz cierni, głogów i ziół jadowitych, rumowiska skał ogromnych, zielone całe od wilgotnych mchów, a wśród nich ona sosna. Stoi i gałęzi ma sześć, niczym sześć rąk zielonych, a jedna z nich dziwna, magiczna.

Las ten niczym się nie różni od tysiąca innych, na innych wzgórzach świata, spotykanych lasów. A i sosna taka sama się wydaje, nie różna od tysiąca innych sosen.

Z czubku czubeczku wzgórza widać cały widnokrąg krainy - góry, pola, lasy, wody. Wioski, huty wielkie, domy, fabryki, miasteczka. Takie mnóstwo, że nie zliczyć. A leżą jakby obraz malowany, a tak cudny, że zda się patrzeć na niego sto lat, i nie napatrzyłby się nikt dosyć jeszcze.

Wschodził świt.

Na dole wzgórza trwało jeszcze ciemne rano. Miasto całe jeszcze spało. Jeszcze złoto nie złociło, jeszcze szyby ludzkich domów nie dotykał promień słońca.

Od czubku czubeczku wzgórza światło szło w dół leśnymi zboczami. Blask dymny i deszczowo mętny, nie rozwidniał przedmiotów, tylko odgraniczał je nawzajem od siebie. Złotawym kurzem osiadając na grzbietach drzew.

Na niskiej i niby na jeża ostrzyżonej murawie stała sosna rozłożysta i sześcioma rękami-gałęziami szumiała do nadchodzącego słońca.

Którą pierwszą, którą pierwszą, którą pierwszą rękę, dotknie światła promień.

Sosna stała dosłownie. Gdyż zdawało się, że w miejscu zetknięcia z murawą kończy się i nie zapuszczając w ziemię prawie korzeni, samą podstawą rozszerzonego u dołu pnia gruntuje się i równoważy na powierzchni. Ale gdzie miała sosna te korzenie zapuszczać, jeśli pod nią ziemi ledwo co. Nie dużo, trochę ziemi tylko, a pod spodem gruzy. Tyle co w sto lat ledwo można zrobić, z siostrami sosnami z igliwia ulepić, z opadłych liści. 
I stała więc sosna na sześciu korzeniach, które jak ramiona gwiazdy rozczapierzały się na sześć stron świata. Przeciskając się powoli lecz wytrwale przez gruzy wyburzonego miasta, z którego usypane było wzgórze.

I chociaż ludziom się wydaje, że drzewo jakie jest wszyscy wiemy. To pamiętać trzeba, że drzewo widzimy zawsze do połowy. Drugą część wyobrażając sobie tylko, a często tej tajemniczości nie potrafiąc wyobrazić sobie wcale. I w dumnej swej wiedzy myśląc, że tam gdzie nasz wzrok nie sięga, tam i patrzeć nie ma po co.

A czego tam we wzgórzu nie było.

Gruzów ogrom. Cegły czerwone, beton, kurz, pyły, belki stropowe. Roztrzaskane nagrobki z marmuru, lastryku, granitu. Ludzkie śmieci, co się razem ze zburzonymi domami rozpadły. Wszystkie rzeczy ludzkie, których nie chwyta się na ręce, kiedy z domu uciekać trzeba. I tyle co na plecy, do wózka małego można chwycić, wziąć, zabrać, do nowego domu ponieść.

Jeszcze bruk uliczny, kamienie dawno z pola wyrżnięte, okruszki kościołów, synagogi, zboru. Nawet pomników kawałki, metale, gwoździe stare i rdza.

A pomiędzy tymi wszystkiemi przeciskają się, rozczapierzają korzenie sosny. I który korzeń na który odłamek trafi, tego pieśni dotyka, przytula, pieści się razem z nim w gruzowym uścisku.

Wschodził świt.

Jak błyskawica płynie z korzenia pieśń niesiona wodą, do góry, do góry, coraz wyżej, coraz wyżej. Przez gruzy i pyły, przez ziemię płytką, pniem sosnowym płynie przez ciało sosnowe. Coraz wyżej, coraz wyżej, aż sięga sosnowej ręki-gałęzi.

Mało-ostre igiełki słońca dotykają pierwszej ręki sosnowej. Roztapiają się w niej blaskiem słonecznym, żółto-czerwonym rozlewają.

Drzewo zaszumiało głośniej. Ręka wyciągnęła się, zamruczała cała i drzewnym głosem zaczęła śpiewać. A w śpiewie tym dało się słyszeć te słowa:

\section{Opowieść pierwsza. 0 tym jak hrabina przybywa do Breslau}

Okna otwórzcie, wywietrzcie ten dom.

Czas podłogę tu zmieść, Do izb niech zawita blask.

Niechaj wszystko odzyska znów sens.

Dla mioteł już czas.

Gdy powiedzie się plan, Wróci świat do swych ram, Lada dzień.

Niech idą w kąt i smutek i żal. Wyrzućcie je precz. 
Pewnego razu, niewiele przed zaduszkami, do miasta Breslau przyjechała wraz ze swym narzeczonym pewna elegancka, wyjątkowo gustowna hrabina. Na imię było jej Dina. To miłość przywiodła hrabinę do Breslau, gdyż kilka miesięcy wcześniej poznała w dalekim Paryżu skromnego niemieckiego nauczyciela, który przyjechał do francuskiej stolicy uczyć się języków. Poznali się i zakochali w sobie jak dwie synogarlice niewinne.

Hrabina wiedziona nadzieją prawdziwej miłości podąża za nauczycielem do jego rodzinnego miasta.

Za trzy miesiące ma odbyć się ślub.

Zatrzymuje się najpierw w hotelu du Nord. Tam spędza pierwsze dni. Przybywa do miasta bez przyjaciółki, bez pokojówki nawet, a nie uchodzi przecież młodej damie z dobrego domu mieszkać samej. Postanawia więc wynająć pensję, dwa pokoje góra. (Niedługo potem tłumaczy swojej nowej gospodyni, że jej towarzyszka zaniemogła w trasie i stąd wynika ta nieobyczajna nieobecność.)

Z hotelu przyjeżdża powóz wynajęty, a w nim bagaże, kufry eleganckiej damy. Czego tam nie było: suknie drogie i jedwabne, codzienne, poranne, wieczorowe. Niektóre czerwone, a inne w zupełnie innych kolorach. (Jedną z nich Dina ubiera już w hotelu du Nord. Gdy schodzi po schodach, kelnerzy mówią o niej „To schodzi królowa Luiza”).

Potem długi szal jedwabny, różowa halka, paryskie kapelusze, butów cała kolekcja. Obrazy i lampy weneckie, toaletowe przyrządy, wachlarz z kości słoniowej, a wszystko z wygrawerowanymi inicjałami A.P. i herbową koroną z siedmioma ząbkami. Potem dwa męskie garnitury (Mówi, że ubiera je tylko na karnawał), sztylet z uchwytem wysadzanym perłami, (który ofiarował hrabinie brat, brazylijski oficer marynarki, który po latach służby ojczyźnie pozbawiony stanowiska umiera z szaleństwa w berlińskim szpitalu).

Potem chustka, którą hrabina z nabożeństwem pokazuje gospodyni (To pamiątka po mojej zmarłej matce, a uszyli ją niewolnicy).

Gospodyni podziwia chustkę, nigdy czegoś takiego nie widziała.

A to jest jej portret - mówi Dina i ustawia oprawiony dagerotyp na komodzie podokiennej.

Hrabina wprowadza się i postanawia przemeblować mieszkanie. Wszystko ma być przemalowane na różowo. Przychodzi tapeciarz, meble wysyła do tapicerowania i wracają całe w aksamitnym różu. Żyrandol ozdabia własnoręcznie. (Zawsze miała rękę do kobiecych robótek). Zamawia paryskie firanki za 75 franków. Na nowych stolikach wszędzie stoją kwiaty.

Dina opiera się ramieniem o różowe ściany i pyta narzeczonego, czy pasuje jej ten kolor. Mówi do niego czule "Schatz", skarbie. 
Pewnego wieczoru siada z gospodynią i opowiada jej swoją historię. Jej imię brzmi Alma Dina de Paradeda i jest córką hiszpańskiego konsula z Brazylii.

Jej imię to Alma Dina de Paradeda i urodziła się w Rio de Janeiro jako dziecko niemieckiego lekarza i brazylijskiej kobiety.

Jej imię to Alma Dina de Paradeda i jej ojczymem jest niemiecki lekarz pochodzący spod Berlina.

Czego ona nie przeżyła. Dziewięć razy przepłynęła ocean, dwa razy statek prawie się rozbił, dwóch panów się zastrzeliło, a trzy damy popadły w obłęd.

Innego razu miał odbyć się wielki bal maskowy, a Dina postanawia przygotować papierowe kwiaty dla wszystkich eleganckich dam. Przez trzy dni siedzi w kajucie, i już nie starcza jej czasu, by przygotować cokolwiek dla siebie. Jeden z panów przychodzi po nią i chce ją zaprowadzić do sali balowej, ale Dina mówi, że nie ma żadnego kostiumu. Pan wpada na pomysł, by przebrała się za neapolitańczyka i daje jej ubrania własnego syna. Dina szybko je zakłada. Gdy pojawia się na pokładzie nikt jej nie poznaje. Wszyscy dziwią się, że hrabina nie przyszła. W końcu woła wśród gości - Czy mnie nie poznajcie? - ze śmiechem opowiada swojej gospodyni.

Tak mijają tygodnie.

Narzeczony przychodzi w odwiedziny w każdą niedzielę i środę, tak jak trzeba. Ona sama bardzo rzadko opuszcza mieszkanie. (Później będą pisać, że ich kontakt był formalny i że Dina bywała chorobliwie zazdrosna.)

Pewnego dnia narzeczona ma zostać przedstawiona rodzinie swojego oblubieńca. Już o szóstej zaczyna się szykować, po półtorej godziny jest gotowa. Ma na sobie suknię z irlandzkiego haftu i gorset ściśnięty tak mocno, że kaszle nie mogąc nabrać powietrza. (Później piszą, że jej talia mierzyła 52 centymetry. I że kobiety docenią znaczenie tych liczb.)

Przeprasza za kaszel. Narzeczony nie daje po sobie nic poznać, ale gospodyni spostrzega, że wstydzi się tej sytuacji. Wszyscy już się zebrali. Cała rodzina w komplecie, samych dzieci było ponad tuzin. Dina jest bliska omdlenia, opiera głowę o ramię narzeczonego, po policzku spływa łza.

Jednak wszystko było tak jak powinno być. Panowie pocałowali Dinę w rękę, kobiety się przed nią się ukłoniły. Usiedli za stołem, służba podała wino, a głowa rodu powitała hrabinę w jej nowej rodzinie. Potem narzeczeni wymienili pierścionki zaręczynowe i wszyscy się ucałowali.

Dina kaszle, a kobiety patrzą na nią ze zdziwieniem, bo kaszel zupełnie nie brzmi tak, jak powinien brzmieć. Potem, sześcioletni syn siostry jej narzeczonego krzyczy, patrząc na nią. Krzyczy, że hrabina nie jest tym, kim przecież wie, że jest. 
A świt nadal wschodził.

Jak błyskawica płynie z korzenia pieśń niesiona wodą, do góry, do góry, coraz wyżej, coraz wyżej. Przez gruzy i pyły, przez ziemię płytką, pniem sosnowym płynie przez ciało sosnowe. Coraz wyżej, coraz wyżej, aż sięga sosnowej ręki-gałęzi.

Mało-ostre igiełki słońca dotykają drugiej ręki sosnowej. Roztapiają się w niej blaskiem słonecznym, żółto-czerwonym rozlewają.

Drzewo zaszumiało głośniej. Ręka wyciągnęła się, zamruczała cała i drzewnym głosem zaczęła śpiewać. A w śpiewie tym dało się słyszeć te słowa:

\section{Opowieść druga. $O$ berlińskich balach}

Od późnych godzin wieczoru aż kolejny dzień nadejdzie.

Chodzimy po Friedrichstrasse tak jak zawsze.

Ramię w ramię. Tam i z powrotem. Noga za nogą.

Chodzimy, wyszykowani tak jak zawsze.

Skromność nie jest dobra dla interesów.

To jest pierwsza chłopców zasada, bądź zawsze modny i elegancki.

A drugą zasadą jest spokój i mówienie czasem nie.

Nigdy nieśmiało, nigdy powściągliwie.

I końcowo, jeżeli chcesz się wzbogacić.

Trzecią zasadą jest szantaż.

Działo się to w wielkim mieście Berlin na początku poprzedniego wieku, w czasach których już nikt prawie nie pamięta. Różne są miasta na świecie, tak jak różne są kraje i ludzie w nich żyjący. Ale miasta takiego jak Berlin, jak świat długi i szeroki nie znajdziecie.

Znany jest z rozrywek, których nigdzie indziej nie uświadczysz. (Jeśli wiesz kogo spytać, i jeśli wiesz, na kogo chcesz trafić.)

Od jesieni do wiosny, nawet kilka razy w tygodniu, organizowane były bale, ogromne, na tysiąc osób lub więcej. Trzeba sporo zapłacić, (jak wieść niesie). Ale każda marka jest warta swej ceny.

Ważni przybysze, a czasem nawet obcokrajowcy, którzy życzą sobie zobaczyć coś nadzwyczajnego, (jeśli wiedzą kogo spytać i wiedzą na kogo chcą trafić). Prowadzeni są przez możnych tego miasta, na jeden $z$ bali. 
W tamtym czasie żył w mieście Berlin pewien mężczyzna. W średnim już wieku, ale nadal pełen wigoru. Był to znany lekarz, specjalista światowej sławy, którego imię zapisało się w annałach i kartach historii. I brzmiało ono Magnus Hirschfeld.

Lekarz postanawia odwiedzić bal, cieszący się sławą pierwszy bal w roku, który dzieje się zawsze w pierwszą sobotę po pierwszym stycznia. Jest 1903 rok.

Kiedy doktor przestępuje próg sali, jego oczom ukazuje się oślepiająco oświetlona przestrzeń. Chyba nawet na 800 osób. Około godziny 10 nie ma jeszcze żywej duszy, a światło drży, jakby w oczekiwaniu.

Kwadranse mijają i nagle ożywają drzwi.

Jak sznur drogocennych pereł wylewa się z dorożek i powozów barwny ludzki tłum. Kogo tam nie było. Niektórzy w strojach wieczorowych, niektórzy tak jak na co dzień, a jeszcze inni przebrani w kostiumy ze wszystkich możliwych epok. Część przychodzi w szatach mieniących się feerią barw, część przychodzi w sukniach balowych. (Na wielu balach kobiet jest bardzo niedużo, ale są i bale organizowane tylko dla nich.) Twarze zakryte są maskami. Lekarz może tylko się domyślać, jakie twarze na niego spoglądają.

Patrzy na rokokową szlachciankę, która pomaga swej damie wyjść z karety. Za nimi idzie gruby kapucyn, potem marynarz, piekarz, klaun, pomocnik na roli. Potem pierrot, damy w strojach konnych, Japończyk, oficer, potem drobna gejsza. Carmen o płomiennych oczach spogląda na jockeya, ognisty Włoch zawiera głęboką przyjaźń z bałwanem.

Jednego razu lekarz spotka tam Fraulein Katharinę, która jako pierwsza w Berlinie ma pozwolenie by nosić w domu, i w pracy, a nawet na ulicy, męski strój.

Przychodzą i odchodzą i nikt nawet nie wie kim są. Niektórzy swoim wyglądem i ruchami sprawiają wrażenie tak kobiecych, że wyglądają niczym rajskie ptaki. Lekarz myśli, że niektórzy wyglądają niestosownie. Nie ubrali masek, a na twarzach zamaszystą plamą czernią się wąsy.

A środku czeka już policja. Zdjęli mundury, by wtopić się w tłum i pilnują, by nie wydarzyła się żadna niegodziwa rzecz. Ale jak wieść niesie, nie było jeszcze okazji by interweniować. Organizatorzy dbają, by do środka trafili tylko Ci, którzy powinni tam trafić.

Spojrzenie lekarza zastyga na damie w paryskiej sukni wieczorowej. Potem dowiedział się, że była to comtessa Dina - hrabina, która przybyła niedawno z Paryża. A która kilka lat później trafia na nagłówki gazet - fałszywa narzeczona z Breslau, männliche Braut - krzyczą pogrubionymi literami.

Jak wieść niesie, hrabina prowadzi w Berlinie bardzo elegancki dom. Przywiozła ze sobą służbę, meble i wszystko co w domu być powinno. Przyjmuje gości i szybko staje się znana w dobrym środowisku. 
Tylko niektóre damy mają czar zjednywania sobie innych, a Dina jest jedną z takich dam. Niektóre robią to przy pomocy pieniędzy. Niektóre przy pomocy kobiecego uroku.

A ona ma i jedno, i drugie.

O pierwszej w nocy bal sięga szczytu. Potem następuje przerwa na kawę. A potem przychodzą tłumy.

Służba wyciąga długie stoły, zaczynają się występy, śpiewy, tańce, wszystko przygotowane przez berlińskie Damen-imitatoren. (Dina też występuje na balach, jest gwiazdą przez prawie dwa lata.) Tłum posila się przy zastawionych kwiatami stołach, potem usuwa je służba i zaczyna grać orkiestra. Z sąsiednich pokojów słychać jasny śmiech, brzęk szkła, śpiewanie. Żaden niestosowny dźwięk nie psuje radości, aż do momentu gdy ostatnie uczestniczki opuszczają bal przy świetle zimowej jutrzenki.

A świt nadal wschodził.

Jak błyskawica płynie z korzenia pieśń niesiona wodą, do góry, do góry, coraz wyżej, coraz wyżej. Przez gruzy i pyły, przez ziemię płytką, pniem sosnowym płynie przez ciało sosnowe. Coraz wyżej, coraz wyżej, aż sięga sosnowej ręki-gałęzi.

Mało-ostre igiełki słońca dotykają drugiej ręki sosnowej. Roztapiają się w niej blaskiem słonecznym, żółto-czerwonym rozlewają.

Drzewo zaszumiało głośniej. Ręka wyciągnęła się, zamruczała cała i drzewnym głosem zaczęła śpiewać. A w śpiewie tym dało się słyszeć te słowa:

\section{Opowieść trzecia. 0 dzieciństwie hrabiny}

Gdy Dina miała tylko sześć lat, miała przyjaciela. Dziecko ogrodnika, mieszkające o dwa kroki od jej rodzinnego domu. Gdy chciała go odwiedzić, musiała przejść przez kładkę, która oddzielała ich domostwa. Potajemnie przynosiła mu zawsze najpiękniejsze owoce z kuchennego stołu.

Gdy pewnego dnia chciała przebiec przez mostek do domu przyjaciela, wygrzewały się na nim dwie jaszczurki całe ozłocone słońcem. I wydawało się jej, że widzi dwa smoki ogromne, które strzegą mostu i nie pozwalają przejść. Przerażona dziewczynka uklękła i zaczęła modlić się do Boga, by odesłał te potwory. A ona w zamian już nigdy nie będzie kraść owoców ze stołu.

Modli się na kładce wiele godzin. Klęczy na twardych mostkowych deskach, ale jej Bóg nie zabiera zwierząt do siebie. Nagle słyszy wołanie "Comtessine” Hrabianko!, to woła do niej guwernantka. Za nią biegnie ogrodnik i zanosi ją w ramionach do domu. Dina nie może chodzić i następnego dnia ma ciężką gorączkę. 
Gdy Dina była jeszcze dzieckiem, jej tata wynajduje mydło w płynie. Robi to w prezencie dla jej matki, która bardzo dba o swoją skórę. Mydło odnosi sukces i zaczynają produkować je masowo. Gdy ojciec umiera, biznes staje się spółką akcyjną. Do dzisiaj widać w Ameryce te małe flakoniki.

Pamięta dobrze dzień, gdy umarł. Wychodził właśnie do parku, Dina siedziała w salonie z przyjaciółmi domu i zadano pytanie, czy służący powinni nosić białe czy czarne pończochy. Nagle do salonu wchodzi sprzątaczka i mówi przerażona, blada jak śmierć: Proszę się nie przerazić, ale pan ciężko zachorowat.

Gdy Dina ma lat 15, często idzie na wybrzeże. Podczas sztormu lubi sprawdzać siłę swego głosu. Chce krzyczeć głośniej niż fale. W okolicy nie ma innych domów, więc może kąpać się z matką jakby morze należało tylko do nich. Matka ostrzega ją, że może pływać tylko w określonych godzinach, ale jednego razu ignoruje ostrzeżenia. Wypływa i widzi płynącą w swoją stronę olbrzymią falę. Zaczyna się modlić. Myśli o mamie, której nigdy więcej nie zobaczy, a fala wypycha ją na brzeg. Dina uznaje to za ostrzeżenie od Boga i postanawia nigdy już nie igrać z losem.

Gdy ma lat 17, kilka miesięcy spędza w sanatorium. Całymi dniami robi róże z jedwabnego papieru. Potrafi je przygotować najpiękniej ze wszystkich. Jej kwiaty zawsze muszą być nienaganne. Raz, specjalnie dla swojej mamy, przygotowuje gałązkę papierowych chryzantem, a ta trzyma je na honorowym miejscu przez pięć lat, tak bardzo były piękne.

I świt nadal wschodził.

Jak błyskawica płynie z korzenia pieśń niesiona wodą, do góry, do góry, coraz wyżej, coraz wyżej. Przez gruzy i pyły, przez ziemię płytką, pniem sosnowym płynie przez ciało sosnowe. Coraz wyżej, coraz wyżej, aż sięga sosnowej ręki-gałęzi.

Mało-ostre igiełki słońca dotykają drugiej ręki sosnowej. Roztapiają się w niej blaskiem słonecznym, żółto-czerwonym rozlewają.

Drzewo zaszumiało głośniej. Ręka wyciągnęła się, zamruczała cała i drzewnym głosem zaczęła śpiewać. A w śpiewie tym dało się słyszeć te słowa:

\section{Opowieść czwarta. O płonących książkach}

Kilka lat później w wielkim mieście Berlin wydarza się skandal i możni tego miasta zmieniają zdanie. Okazuje się, że dwór cesarza Wilhelma uczęszczał na bale. Że chyba pojawiali się tam zbyt ważni ludzie. Padają nazwiska i insynuacje. Zaczynają się procesy, jeden za drugim.

Od tego czasu bale są zabronione, nikt tylko nie potrafi wskazać prawa, dla którego tak się dzieje. Coś się zmienia. Powietrze pachnie inaczej i nic już nie jest takie, jakie było wcześniej. 
Lekarz przypomina sobie, jak spotkał jednego ze starych niemieckich hrabiów na Unter den Linden. Pyta go, jak mu się powodzi, a ten zdruzgotany odpowiada, że niestety wcale nie jest dobrze. Lekarz boi się przez chwilę, że hrabia wpadł w ręce szantażystów, ale powód okazuje się inny. Hrabia kazał uszyć wspaniałą suknię w najlepszym paryskim salonie, a ona nigdy nie używana wisi w szafie. Kiedy suknia przyjeżdża z odległego Paryża, bale są już zakazane. Wieść niesie, że nigdy więcej się nie wydarzą.

Dwadzieścia siedem lat później, 6 maja, około 9:30 rano ponad setka studentów i studentek przyjeżdża w ciężarówkach przed Instytut prowadzony przez lekarza.

Jest to przestronna willa, wcale niedaleko Reichstagu. Jak wieść niesie, budynek jest prawie pusty. Zostało tylko kilku pracowników. Lekarz już kilka miesięcy wcześniej uciekł z kraju. Wybiegają z ciężarówek i biegną do środka, wybijają drzwi. Za nimi podąża orkiestra dęta, która idąc przygrywa studentom do rytmu.

Najpierw wpadają do biblioteki, w której przez lata działalności Instytutu, staraniem wielu osób znalazło się ponad dwadzieścia tysięcy tomów. Imponujące zbiory z całej Europy i świata. Mają ze sobą listę i systematycznie, półka po półce, książka po książce, zdejmują z półek teksty, które na liście się znalazły. Niosą je obładowani z powrotem do samochodów. Potem wracają i zajmują się tym co jest na ścianach: zrywają obrazy, fotografie, plakaty. Roztrzaskują gabloty z eksponatami. Pracują wytrwale. Imponujące zbiory z całej Europy i świata, które staraniem wielu osób znalazły się w Instytucie, to ponad 5 tysięcy przedmiotów.

W południe kończą pracę. Zbierają się przed budynkiem. Coraz więcej gapiów. Wokół zbiera się tłum. Jest przemowa, a potem orkiestra zaczyna grać i śpiewają wspólnie.

Podnieść chorągiew, szeregi mocno zwarte.

SA to marsz. Spokojny, równy krok.

Nasi towarzysze zastrzeleni przez komunę i reakcjonistów.

Maszerują duchem w naszych oddziałach.

Oczyść ulice dla brązowych batalionów.

Oczyść ulice dla tego co niesie sztorm.

Miliony patrzą z nadzieją na hakenkreuz.

Świta dzień wolności i chleba.

Ostatni już raz, wybrzmiewa nasz apel.

Wszyscy jesteśmy przygotowani na walkę. (...)

Czas niewoli potrwa już tylko chwilę. 
Po południu pojawia się kolejna grupa. Tym razem w uniformach, bardziej dystyngowana, spokojna, to członkowie SA. Szperają w zniszczonych szufladach, metodycznie zbierają kwestionariusze i karty pacjentów. Wszystko chowają w szarych teczkach.

Trzy dni później książki płoną na placu przy Unter den Linden. Wieść niesie, że patrzy na to 40 tysięcy ludzi. Orkiestra gra pieśni ludowe i wojskowe marsze, a wszystko transmituje rozgłośnia radiowa. Dziewięciu studentów zajmuje się ceremonią.

Do ognia podchodzi uroczyście pierwszy. Wrzuca książkę i mówi:

Przeciwko walce klasowej i przeciwko materializmowi. Dla społeczności narodowej, dla idealistycznego stylu życia, ogniowi powierzam teksty Marxa i Kautsky'ego.

Drugi podchodzi do ognia i mówi: Przeciwko dekadencji i moralnemu upadkowi. Dla dyscypliny, moralności w rodzinie i narodzie, ogniowi powierzam teksty Manna, Glaesera i Kastnera.

Potem do ognia podchodzi trzeci, czwarty, piąty. Szósty, siódmy, ósmy i dziewiąty student.

A świt nadal wschodził.

Jak błyskawica płynie z korzenia pieśń niesiona wodą, do góry, do góry, coraz wyżej, coraz wyżej. Przez gruzy i pyły, przez ziemię płytką, pniem sosnowym płynie przez ciało sosnowe. Coraz wyżej, coraz wyżej, aż sięga sosnowej ręki-gałęzi.

Mało-ostre igiełki słońca dotykają drugiej ręki sosnowej. Roztapiają się w niej blaskiem słonecznym, żółto-czerwonym rozlewają.

Drzewo zaszumiało głośniej. Ręka wyciągnęła się, zamruczała cała i drzewnym głosem zaczęła śpiewać. A w śpiewie tym dało się słyszeć te słowa:

\section{Opowieść piąta. O tym jak hrabina umiera}

Pewnego szczególnie pięknego dnia, gospodyni proponuje Dinie wspólny spacer do Parku Szczytnickiego Scheitniger Park. Hrabina mówi obrażonym tonem, że tak szybko to ona się nie ubierze. Gospodyni uspokaja, niech się panienka nie śpieszy, bez panienki nie pójdziemy.

Ale Dina jest zdenerwowana. Zaczyna mówić w obcych językach, nie może zapiąć paska, obiad zbyt jej dziś smakował. Nie umie założyć sama sukni. Wysiłek sprawia, że na jej czole pojawia się pot. Córka gospodyni musi jej poprawić makijaż. W końcu jest gotowa, wychodzą na ulicę. 
Idą przez park. Nie ma tam zbyt wielu ludzi, z czego wszystkie się cieszą, bo Dina zawsze przyciąga spojrzenia. (A przecież tak nie wypada, tyle spojrzeń na sobie mieć.)

W końcu zatrzymują się przy pomniku Schillera. Gospodyni zauważa, że stojący wokół nich ludzie przypatrują się hrabinie, a nie pomnikowi.

Ale Dina patrzy tylko na pomnik. Omija ludzkie spojrzenia, cicho odczytuje inskrypcję wykutą złoconymi literami na cokole. Alle Menschen werden Brüder - Wszyscy ludzie będa braćmi. Chwyta córkę gospodyni za rękę. Drugą rękę wyciąga do jej matki i śmieje się figlarnie.

A potem szepcze do nich: A my tutaj jak jakie siostry stoimy.

Narzeczony przepadł bez wieści.

Dinę znowu napadają bóle nerwowe. Chce dzwonić po zaufanego lekarza, który miał jej przepisać zastrzyk z morfiną. Lekarz miał przyjść o dziewiątej, ale nie zjawia się osobiście. Wysyła swojego asystenta, który pyta, jak Dina się czuje i daje jej zastrzyk. Hrabina kładzie się do łóżka, ale i tak nie może zasnąć. Rano wstaje z zawrotami głowy.

Nastaje kolejny słoneczny dzień. Zwierza się gospodyni, że jeśli w końcu przyjdą pieniądze, na które czeka już tak długo, ucieknie jak ptak z tego nieszczęsnego miasta. Gospodyni prosi ją, by poczekała jeszcze parę dni. By poczekała aż będzie silniejsza i zdrowsza. Dina przyznaje jej rację, w swoim stanie jest bezradna jak dziecko. Nadchodzi pora obiadowa.

Jeszcze nie uprzątnięto stołu, gdy nagle słyszą dzwonek u drzwi. Ding dong.

To wrócił lekarz. Dina żali się doktorowi, że nie spała całą noc, mimo że asystent wstrzyknął jej dawkę morfiny. I że już od tygodnia nie może spać. Że cierpi na bóle duszy. Lekarzowi jest bardzo przykro, pyta, co się stało. Dina mówi, że opuścił ją narzeczony.

Ale na pytanie, dlaczego, odpowiada, że nie wie.

Lekarz patrzy na nią łagodnie i pyta: Może chciałaby mi Pani powiedzieć coś w sekrecie?

Lekarz domaga się, by ją zbadać, ale hrabina nie chce się na to zgodzić, pozwala badać się tylko zaufanemu lekarzowi.

Jeszcze nie uprzątnięto stołu, gdy nagle słyszą dzwonek do drzwi. Ding dong.

Pojawia się dwóch urzędników z wydziału kryminalnego. Mają ze sobą nakaz badania lekarskiego. 
Okazuje się, że gdy ostatniej niedzieli narzeczony zniknął bez śladu, pojechał do swojego przyjaciela i skarżył mu się, żalił. To był ten sam przyjaciel, który z taką z nieufnością patrzył na Dinę. Po rozmowie narzeczony idzie na policję i składa donos. Potem wyjeżdża.

Jeszcze nie uprzątnięto stołu, gdy nagle słyszą dzwonek do drzwi. Ding dong.

To przyszedł lekarz policyjny. Ma ze sobą nakaz badania lekarskiego. Okazuje się, że gospodyni złożyła donos na policji. Zauważyła kiedyś przez niedomknięte drzwi jak Dina goli się w łazience. Myśli, że hrabina jest przestępcą, szpiegiem.

Jeszcze nie uprzątnięto stołu, gdy nagle słyszą dzwonek do drzwi. Ding dong.

W mieszkaniu pojawia się komisarz kryminalny. Ale nie znajduje żadnej podstawy do aresztowania. To narzeczony zawiadomił policję, bo Dina próbowała włamać się do jego mieszkania. Boi się jej zazdrości. Komisarz chce rozmawiać na osobności z gospodynią. Pyta ją, czym hrabina zajmuje się całe dnie. Gospodyni odpowiada, że robią róże z papieru. Komisarz uspokojony wychodzi.

Jeszcze nie uprzątnięto stołu, gdy nagle słyszą dzwonek do drzwi. Ding dong.

Dina zgadza się w końcu na badanie. Chce tylko przebrać się w pokoju toaletowym. Wstaje i idzie do niego sama. Nagle słyszą jakiś straszny jęk. Jęk przeradza się w krzyk, hrabina leży na sofie, krzyczy i wije się z bólu. Lekarz pyta gospodynię, czy hrabina miała częściej takie ataki. Gospodyni na to, że miała, ale nigdy tak straszne.

Nagle hrabina upada na dywan i nie wydaje z siebie już żadnego dźwięku. Z jej piersi wydobywa się ostatni wydech, po którym hrabina nie oddycha już więcej. Okazuje się, że otruła się w pokoju, umiera.

Dina zgadza się w końcu na badanie. Chce tylko przebrać się w pokoju toaletowym. Wraca z niego po pół minuty i ze słowami "Proszę bardzo panie doktorze" siada naprzeciw niego. Za chwilę trucizna zaczyna działać. Dina zaczyna głośno krzyczeć i upada w konwulsjach.

Po chwili umiera.

A świt nadal wschodził.

Jak błyskawica płynie z korzenia pieśń niesiona wodą, do góry, do góry, coraz wyżej, coraz wyżej. Przez gruzy i pyły, przez ziemię płytką, pniem sosnowym płynie przez ciało sosnowe. Coraz wyżej, coraz wyżej, aż sięga sosnowej ręki-gałęzi.

Mało-ostre igiełki słońca dotykają drugiej ręki sosnowej. Roztapiają się w niej blaskiem słonecznym, żółto-czerwonym rozlewają. 
Drzewo zaszumiało głośniej. Ręka wyciągnęła się, zamruczała cała i drzewnym głosem zaczęła śpiewać. A w śpiewie tym dało się słyszeć te słowa:

\section{Opowieść szósta: 0 królewiczu i rybaku}

Włosy Diny już od dzieciństwa są złote, długie i układają się w delikatne fale. Ma duże upodobanie do pierścieni, ale inne dzieci drwią z tego. Patrzą krzywym okiem.

Gdy hrabianka była mała, szczególnie umiłowała sobie starą książkę dziadka pełną orientalnych opowieści. A w książce umiłowała jedną szczególnie bajkę. Do innych wcale niepodobną.

Była to bajka o królu i rybaku.

Żył sobie kiedyś król z czarnymi włosami i ciemnymi oczami. Jego włosy były miękkie i lśniące jak u nowonarodzonego baranka. Gdy spojrzało się w jego oczy, to tak jakby spoglądało się w głębokie jeziora, a twarz jego była dobrotliwa, lecz król nigdy się nie śmiał.

Wszyscy kochali króla, ale on nikogo nie kochał.

Możni jego królestwa chcieli dla niego żony. Ale on wiedział, że nie może spełnić ich życzeń, nawet gdyby przedstawiono mu księżniczki ze wszystkich krajów sąsiednich. Opowieści o ich uroku sprawiały, że czuł tylko smutek. Nie pożądał ich, ale szukał wzrokiem czegoś, czego przy nim nie było.

Pewnego dnia spacerował brzegiem swojego morza, kiedy spostrzegł młodego rybaka. Ten wyciągnął do niego rękę i zabrał go w rejs. Przez całą drogę rybak patrzył na niego z zachwytem, a młody król zobaczył w nim samego siebie. Do pałacu królewskiego wrócili już razem. Król kazał uszyć dla rybaka piękne szaty i nie poruszał się nigdzie bez niego.

Od tej pory król stał się radosny. Na jego twarzy zagościł uśmiech i już się nie smucił. Ale niedługo dane mu było zaznać szczęścia. Nienawiść możnych tego królestwa dosięgła młodego chłopca, który zdobył przychylność króla. Uznali, że rybak przyniesie krajowi nieszczęście i umówili się, by zamordować go pod osłoną nocy.

Król popadł w rozpacz i nie minęło kilka miesięcy jak umarł z tęsknoty i żalu. Pochowano go w mauzoleum, które kazał zbudować dla zamordowanego chłopaka. I tak leżeli, ciało przy ciele, przez kilka lat. Po jakimś czasie, ich trupia bliskość zaczęła przeszkadzać możnym tego królestwa. Ciało rybaka przeniesiono do oddzielnego grobowca.

I w tym momencie właśnie, ostatnia ręka sosnowa, ostatnią baśń wyśpiewała.

I nadszedł dzień. 
Skąpał się las w świetle słonecznym. Całe wzgórze w świetle się rozkokosiło, świeżym podmuchem dnia nacierając liście. Każdą roślinną nóżkę, każdą trawkę, każdą liściastą rączkę otulając złotem. Wiatr niebieskawo zatrząsł drzewami. Po gałęziach wesoło skakały wiewiórki. Dzięcioły pukały a wróżkakukułka kukała wesoło.

Krucha kora sosen, odstając na sękach, perliła się w świetle porankowym. A różowomleczne pnie wilgotnych i zawsze chłodnawych brzóz, to bielały, jak smukłe śnieżki. To różowiały na kształt nóg bocianich.

I wtedy. W tym bezwstydnym świetle dnia. Stało się to, co odbywać się powinno tylko w czarnym wstydzie nocy. Stało się to, co się nie zawsze i nie każdemu przytrafia.

Sosna wzięła się za siebie. W sobie się cała zatrzęsła. Zachwiała się dumnie w swych posadach i wyrwała jeden po drugim sześć korzeni, sześć swoich nóg drzewiastych, z usypanego z gruzów wzgórza.

Wpierw wyciąga pierwszą nogę. Coraz wyżej, coraz wyżej.

Potem. Wyciąga drugą nogę. Coraz wyżej, coraz wyżej.

Za nią trzecia,

Potem czwarta, potem piąta.

A kiedy szósta noga od gruntu się odrywa, kiedy cała drapaga korzeniowa wykorzenia się z murawy. Wtedy sosna samą siebie dosiada jako miotłę latającą i podrywa się w powietrze. Harcuje po niebiosach z rozpuszczonymi na wiatr gałęziami. Szybko zlatuje w dół zboczem, coraz niżej, coraz niżej ku złotemu miastu i powiewa dywanem sosnowych igieł. Wichrzy się ogoniasto.

Leci by bajać ludziom swoje sześć opowieści.

Przyleciała nad miasto, siada na gościńcu i czeka.

Idzie dziecko do szkoły z książką pod pachą. Sosna przed nim staje i rzecz swą przekłada. Dziecko sięga do kieszeni, wyjmuje scyzoryk, sosnę rzeza i w nogi drapie. Sosna rzuca się w stronę przeciwną. Kuli na skraju drogi, skrzypi, wyje żałośnie.

Sześć rąk podnosi ku słońcu i użalać się zaczyna.

A słońce mówi: A czemuś nie udała się do człowieka? 
Sosna zdziwiona odpowiada: A ten kto taki, jak nie człowiek?

On nim dopiero będzie kiedyś - mówi na to słońce.

Sosna kiwnęła głową. Pobiegła, staje znowu na gościńcu i czeka. Idzie myśliwy z karabinem w ręku. Sosna zbliża się ku niemu, a on wziął ją na cel i strzelił.

Sośnie zdaje się, jak gdyby pół pnia jej oderwało. Na gościńcu wszędzie zrąbki, igły, trocinowy pył. Wylewają się lepkim strumieniem krople bursztynowe i miesza się z powietrzem żywiczny zapach rany. Sosna odszumia się, otrząsa z bólu, rzuca się w nogi i hopla do rowu.

Sześć rąk podnosi ku słońcu i użalać się zaczyna.

- Oj, stońce stońce, widzę że mnie oszukujesz... Człowieka szukać kazałaś. Szedł droga z błyszczącym kijem $w$ ręku. Stanąt z daleka przede mna, kij do twarzy przyłożył i plunąt! Ogień błysnąt, dym się zakurzyt, kora w każdą stronę poleciała. A mnie we pniu tak coś ukłuło, że ledwo żyję z bólu.

Słońce odpowiada - Dobrze ci tak... trzeba było udać się do człowieka.

Sosna zdziwiona na to rzecze: A ten kto taki, jak nie człowiek?

- On był nim kiedyś. Powiedziało słońce.

Sosna zaszumiała, zakiwała głową iglastą i pomyślawszy, że na gościńcu trudniej o człowieka, idzie na miedzę i czeka. Nadchodzi kobieta. Sosna przed nią staje i rzecz swą przekłada.

- Z catego serca postucham ja twoich sosno opowieści. - mówi kobieta. Zaczekaj tu chwilkę, a ja szybcikiem wyniose z domu koce do siedzenia, mleko do pijania. Usiądziemy razem, poszumimy razem, mleka popijemy. Bajdurzyć będziemy, opowieścia klechdzić.

Sosna przykuca na pagórku i cieszy się spoglądając za odchodzącą. Wkrótce widzi kobietę z ogromnym ciężarem pod połami. Że aż cała się ugina, dźwigając go przed sobą. Wtem, kiedy kobieta blisko już była, spod kiecki wyskakują dwa psy przeogromne. Rzucają się na sosnę i rozciągają ją na ziemi, tarzając na wszystkie strony.

Ledwo biedaczysko wyrwała się i umknęła za winkiel nieopodalszego budynku. Ale tak była skąsana, że do południa płaczem żywicznym lizała swe rany.

Przyszło południe. Sosna sześć rąk podnosi ku słońcu i użalać się zaczyna.

Któż tobie winien — rzecze słońce - że nie możesz na człowieka trafić?

- Alboż i to nie był człowiek? Dziwi się sosna zasmutniała. 
- To, sosno moja, była kobieta. - powiedziało na to słońce. - I wiedz o tym przecież, że chociaż świat pełen jest ludzi, to człowieka znaleźć trudno. A jeśli już znajdzie się jakiś, będzie on się bardzo różnił od reszty.

Wraca sosna na wzgórze z gruzów usypane. Z podkulonym ogonem posmutniałych rąk, z posmętniałym smętem korzeni-nóg. Na skrzydłach wiatru niesiona. Nie tykając stopą ziemi, leci jakby gołąb dziki.

Odwraca się do góry brzuchem. Koronę sześciu gałęzi zwraca ku murawie, a ku słońcu-niebu sześć korzeni wystawia. Jej ręce-gałęzie drzewiaste zapadają się w ziemię, coraz niżej, coraz niżej. Przez gruzów ogrom, przez cegły czerwone, przez beton, kurz, pyły, belki stropowe. Przez roztrzaskane nagrobki z marmuru, lastryku, granitu. Przez te ludzkie śmieci, co się razem ze zburzonymi domami rozpadły. Wszystkie rzeczy ludzkie, których nie chwyta się na ręce kiedy z domu uciekać trzeba. I tyle co na plecy, do wózka małego można chwycić, wziąć, zabrać, do nowego domu ponieść.

I przez bruk uliczny. Kamienie dawno z pola wyrżnięte, okruszki kościołów, synagogi, zboru. Nawet pomników kawałki, metale, gwoździe stare i rdzę.

A pomiędzy tymi wszystkiemi przeciskają się, rozczapierzają ręcę-gałęzie drzewiaste. I która gałąź, na który odłamek trafi. Tego pieśni dotyka, przytula, pieści się razem z nim w gruzowym uścisku.

I od tego czasu sosna nie wyśpiewa już więcej żadnej opowieści. A wszystko jest inaczej niż wcześniej. Choć wydawać by się mogło, że nic się nie zmieniło.

Podziękowania: Pisząc powyższy tekst korzystałam z analiz źródeł niemieckich, autorstwa Mathiasa Foita.

Utwór powstał na potrzeby Projektu "Złoty kiosk 70/20" organizowanego przez Strefę Kultury Wrocław i grupe ZŁOTY KIOSK przy wsparciu Ministerstwa Kultury i Dziedzictwa Narodowego."

\section{Bibliografia}

Beachy, Robert (2014), Gay Berlin: Birthplace of Modern Identity, New York, Alfred A. Knopf.

„Berliner Pupenjungen" (2014), Piosenka ludowa opublikowana w 1905. Przedrukowana w: Robert

Beachy, Gay Berlin: Birthplace of Modern Identity, New York, Alfred A. Knopf.

Foit, Mathias (2019), "«Męska narzeczona» z Wrocławia”, Replika, 80: 28-30.

Hirschfeld, Magnus (1904), Berlins Drittes Geschlecht, Berlin, Verlag von Hermann Seemann Nachfolger. 
_- (1910), Die Transvestiten, Berlin, Medicinischer Verlag.

(1914), Die Homosexualität des Mannes und des Weibes, Berlin, Verlag Louis Marcus.

Homann, Walter (2010), Tagebuch einer männlichen Braut, wyd. 2, Hamburg, Männerschwarm Verlag.

"Human Again" (1991), The Beauty and the Beast, Muzyka i słowa Alan Menken i Howard Ashman, Walt Disney Pictures, Piosenka usunięta z wersji z 1991 i włączona do Specjalnego Wydania z 2002, https://disney.fandom.com/wiki/Human_Again\#Lyrics

Leśmian, Bolesław (1956a), „Podlasiak”, Klechdy Polskie, Londyn, Katolicki Ośrodek Wydawniczy Veritas.

—_. (1956b), "Wiedźma”, Klechdy Polskie, Londyn, Katolicki Ośrodek Wydawniczy Veritas.

Lewy, Guenter (2016), Harmful and Undesirable: Book Censorship in Nazi Germany, New York, Oxford University Press.

Monatsbericht des Wissenschaftlich-Humanitären Komitees (1907), tom 6, Berlin.

Neugebauer, Franz von (1908), Hermaphroditismus beim Menschen, Leipzig, Verlag von Werner Klinkhardt.

"O wilku i jego przygodach" (1902), Starożytne podania i powieści ludowe z różnych pisarzy zebrane, Poznań, Fr. Chocieszyński.

„Porwany wichrem" (1902), Starożytne podania i powieści ludowe z różnych pisarzy zebrane, Poznań, Fr. Chocieszyński.

Römer, Marie (1907), Mein Zimmerherr. Selbsterlebtes, Breslau, H. Fleischmann-Verlag.

Wessel, Horst (1929), "Horst Wessel Lied", Tłum. własne na podstawie tłum. ang. w: Jean-Denis Lepage, 2016, Hitler's Stormtroopers: The SA, The Nazis' Brownshirts, 1922-1945, Frontline Books, oraz polskiego tłum. z lat 60. XX w. (autor nieznany), https://pl.wikipedia.org/wiki/Horst-Wessel-Lied

Zmorski, Roman (1852), "O dziadowym synu", Podania i baśni ludu w Mazowszu, Wrocław, Zygmunt Schletter.

. (1891), Baśń o Sobotniej Górze z podań śląkich, Warszawa, Józef Jeżyński. 


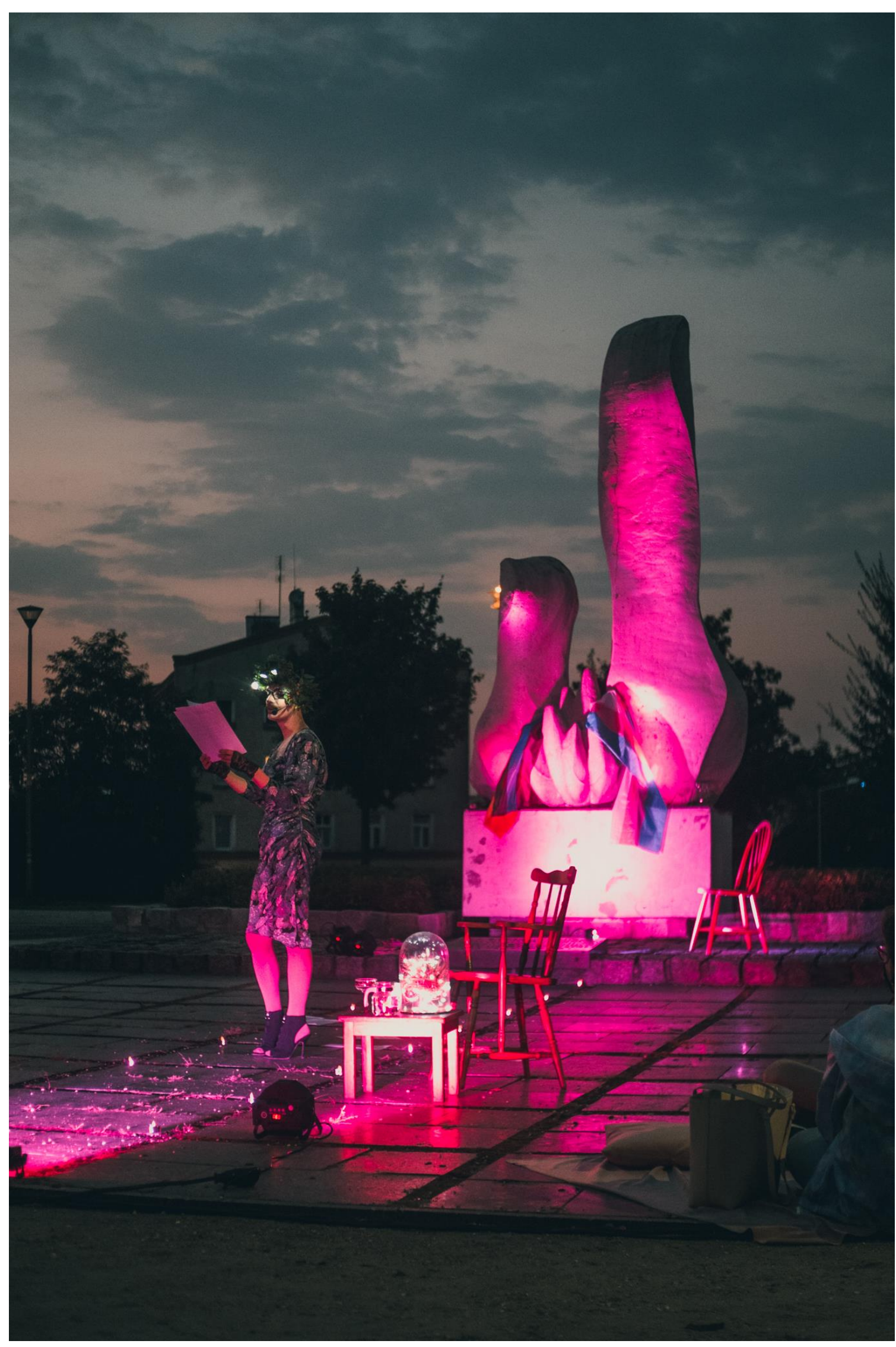

Liliana Piskorska, Sosna z sześcioma rękami, dokumentacja performance, Wzgórze Słowiańskie we Wrocławiu, 2020, fot. Wojciech Chrubasik 


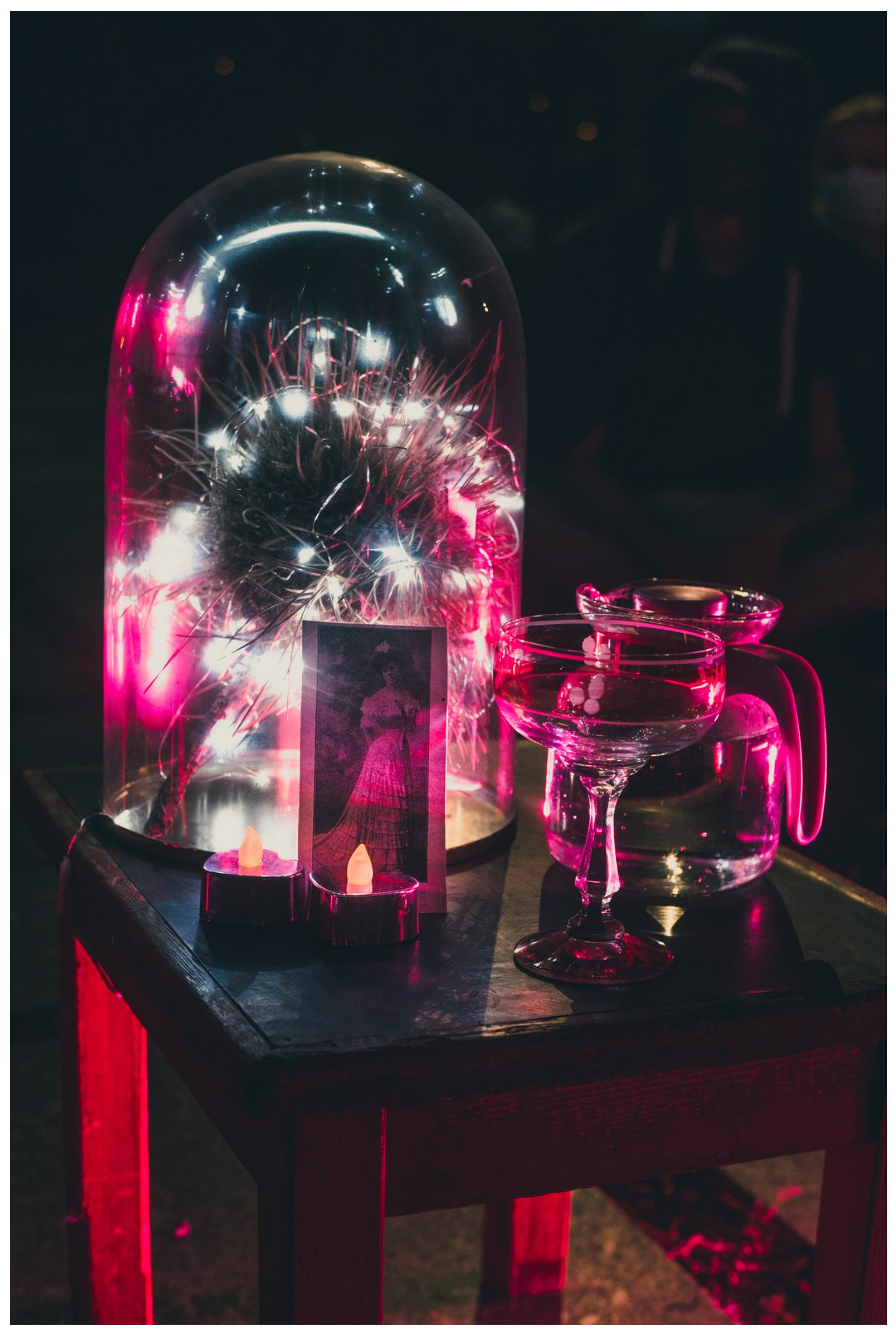

Liliana Piskorska, Sosna z sześcioma rękami, dokumentacja performance, Wzgórze Słowiańskie we Wrocławiu, 2020, fot. Wojciech Chrubasik 


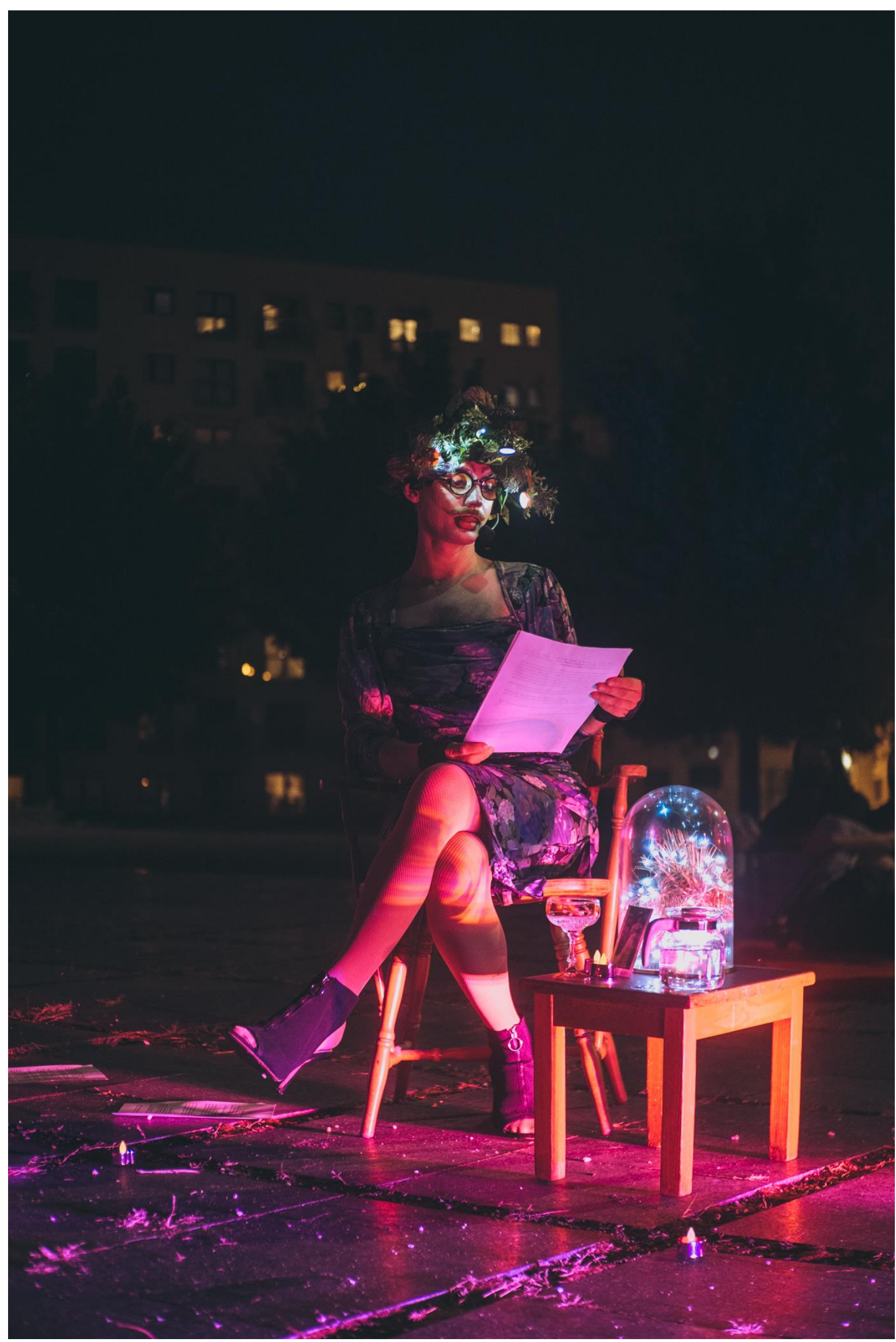

Liliana Piskorska, Sosna z sześcioma rękami, dokumentacja performance, Wzgórze Słowiańskie we Wrocławiu, 2020, fot. Wojciech Chrubasik 


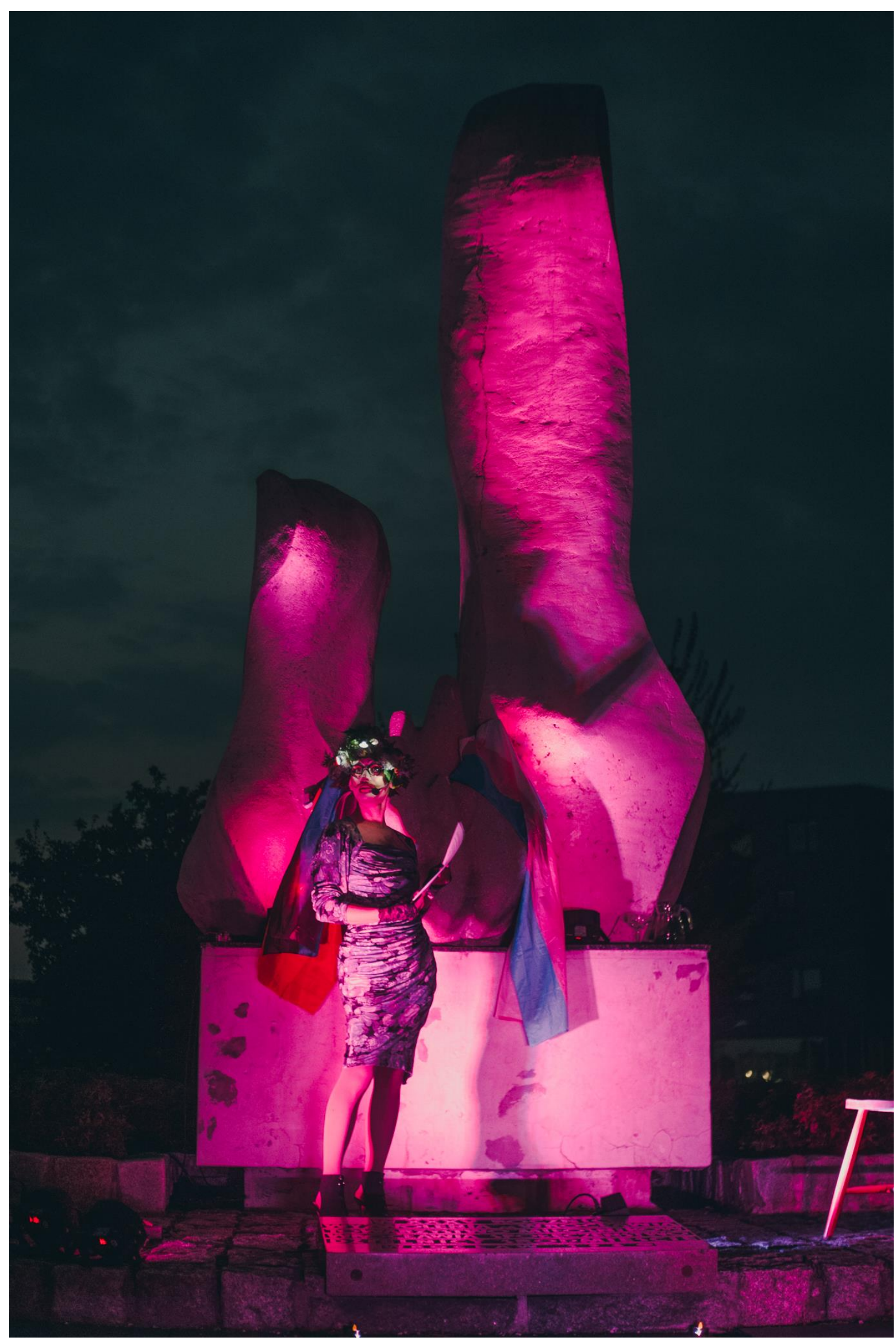

Liliana Piskorska, Sosna z sześcioma rękami, dokumentacja performance, Wzgórze Słowiańskie we Wrocławiu, 2020, fot. Wojciech Chrubasik 


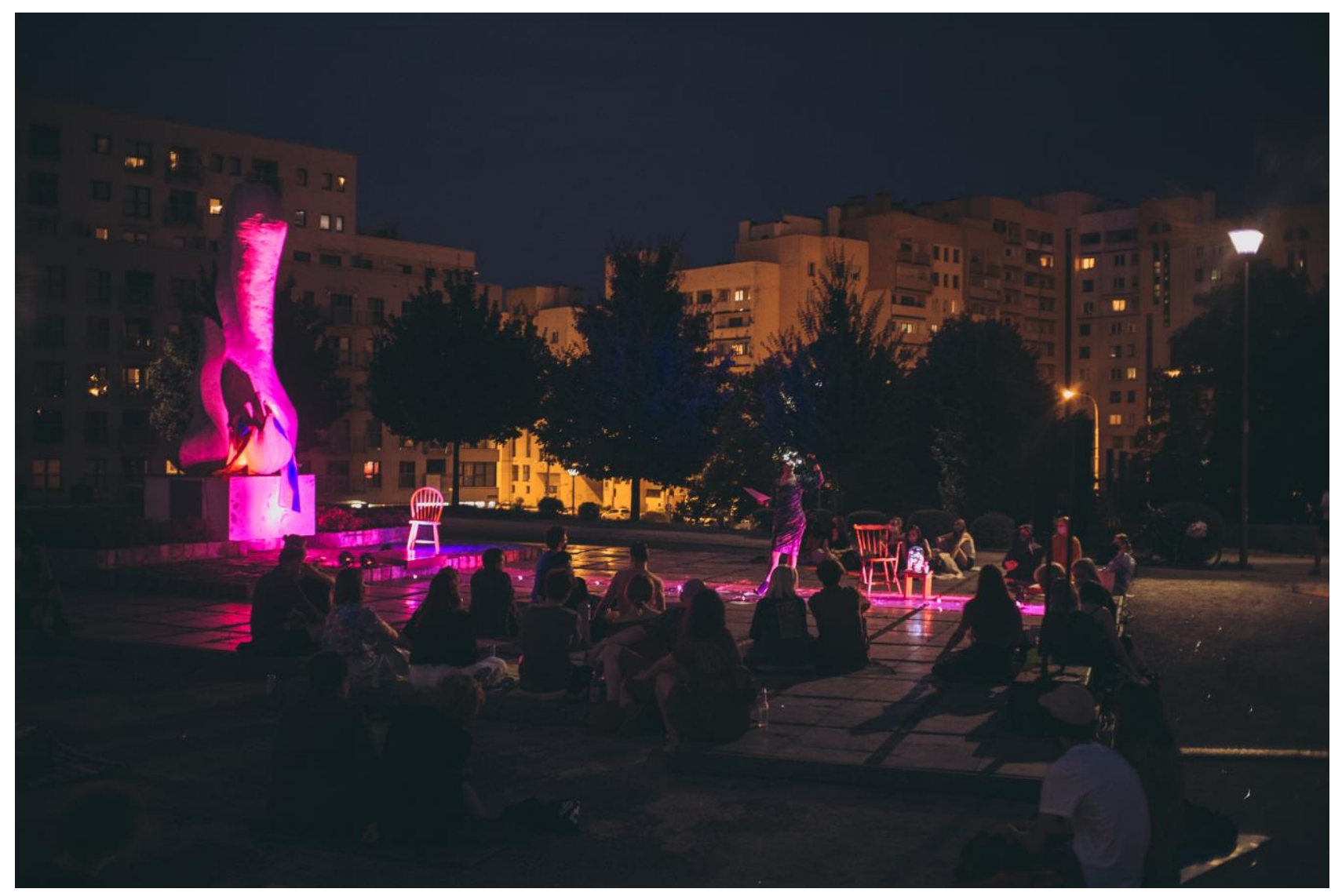

Liliana Piskorska, Sosna z sześcioma rękami, dokumentacja performance, Wzgórze Słowiańskie we Wrocławiu, 2020, fot. Wojciech Chrubasik 